IUFRO division 8.02 - Mendel University Brno (Czech Republic) 2015

"Coppice forests: past, present and future"

Editors: Tomas Vrska, Renzo Motta, Alex Mosseler

\title{
Tree-oriented silviculture: a new approach for coppice stands
}

\author{
Maria Chiara Manetti, Claudia \\ Becagli, Dalila Sansone, \\ Francesco Pelleri
}

\begin{abstract}
Tree-oriented silviculture is an innovative approach of forest management aimed at enhancing a limited number of early-selected crop trees whose growth is favored over the full rotation period by applying frequent thinning in their neighborhood. This approach was originally applied to high forests, but can also be applied to coppices to maintain or improve biodiversity by selecting valuable timber trees and/or minority species as target trees. The main limitation of this silvicultural option is the need of specialized and qualified operators in all the phases, from selection of crop trees to logging operations. In this study, experimental trials were established by the Forest Research Centre of Arezzo (Italy) to verify the suitability of this approach to different struc tural and enviromental conditions. In coppices characterized by fast growing species such as chestnut, tree-oriented silviculture has been applied to a limited number of crop trees (50-100 ha) to obtain more valuable and largersized assortments in a shorter rotation period, reducing at the same time the silvicultural costs. In mixed coppices, where the ordinary management (coppicing) was applied, the abandonment or the conversion into high forest gave rise to a progressive loss in terms of species composition. Contrastingly, thinning focused around a few (5-20) trees of sporadic species allowed to maintain a high level of biodiversity, and led to favorable conditions for growth and regeneration of these species.
\end{abstract}

Keywords: Tree-oriented Silviculture, Valuable Timber, Biodiversity, Thinning Practice

stand dynamics and functionality. The disconnection between silviculture, coppice services and human activity in Italy is a consequence of: (i) the abandonment of rural areas occurred in the second half of the last century; (ii) the prevalence and the fragmentation of private ownership $(66 \%-$ INFC 2005); (iii) the complex and restrictive national and regional laws (Abrami 2002). Moreover, the firewood harvested in Italy has recently become economically unprofitable due to the surplus on the local market of low-cost firewood from abroad (Anonymous 2014). Indeed, Italy is currently the first importer of firewood worldwide, though coppice stands represent the $42 \%$ (3663143 ha) of the total forest area (8 759200 ha - INFC 2005). The most impractices not related to the ownership socio-economics conditions, as well as to

$\square$ CREA - Consiglio per la ricerca in agricoltura e l'analisi dell'economia agraria- Forestry Research Centre, Viale Santa Margherita, 80 - 52100 Arezzo (Italy)

@ Francesco Pelleri (francesco.pelleri@crea.gov.it)

Received: Aug 28, 2015 - Accepted: May 06, 2016

Citation: Manetti MC, Becagli C, Sansone D, Pelleri F (2016). Tree-oriented silviculture: a new approach for coppice stands. iForest 9: 791-800. - doi: 10.3832/ifor1827-009 [online 2016-08-04]

Communicated by: Tomas Vrska portant consequences are a widespread of over-aged stand structures, an extensive degradation of coppices, a decreasing interest in local production and a loss of biodiversity (Mori \& Pelleri 2012).

Nevertheless, some important characteristics of coppices deserve to be safeguarded through a suitable silvicultural approach: (i) they provide wood products in short time; (ii) are strictly linked to the presence of human activities; (iii) supply very important non-wood forest goods (e.g., mushrooms, truffles, fruit berries); (iv) are established on marginal sites (Ducci et al. 2015). To revitalize the coppice system, the silvicultural management should be a combination of different traditional and innovative options, according to site characteristics, stand structure, species composition, ecological efficiency, disturbance factors and societal and economic demand.

Tree-oriented silviculture is an innovative approach in coppice management aimed at enhancing a limited number of crop trees in the forest stand by applying well-defined silvicultural practices. Such approach has been developed in oak and beech high forests of central Europe, in order to produce valuable timber of merchantable size in shorter time with lower costs (Sevrin 1997, Kerr 1996, Bastien \& Wilhelm 2000, Abetz \& Kladtke 2002, Wilhelm 2003, Oost- 
erbaan et al. 2008, Spiecker et al. 2009, Perin \& Claessens 2009, Lemaire 2010, Pelleri et al. 2013) or to preserve and increase the presence of minor tree species (Spiecker 2006, Pelleri et al. 2010, Sansone et al. 2012, Pelleri et al. 2013). Tree-oriented silviculture is based on the early selection of single crop trees within the stand whose free growth is favored over the full rotation period by applying frequent thinning. This strategy can be carried out in coppices both to maintain or improve tree biodiversity, enhancing the sporadic tree species like in mixed coppices (Sansone et al. 2012, Mori \& Pelleri 2014), and to improve the valuable timber trees like in chestnut (Castenea sativa Mill.) coppices (Manetti et al. 2010a). This silvicultural approach may be applied in different types of ownership, in localized but favorable areas, to the whole stand or it can be integrated with traditional silvicultural systems (Fantoni et al. 2012, Melini 2013). Its main limitation is the need of specialized and qualified personnel in all the phases along the rotation period, from the selection of crop trees to logging operations (Manetti et al. 2010b).

The goal of this study is to test two different silvicultural management systems in coppice stands of different age and specific composition, in order to evaluate the growth dynamics of valuable and merchantable trees, and the stand response from an ecological and biodiversity point of view. In particular, we focused on the short- and mid-term differences in tree growth and stand biodiversity in coppices managed under different silvicultural systems, in order to verify the suitability of tree-oriented silvicultural practices to different site conditions and species composition, according to multifunctional criteria.

This study reports the first results of experimental trials established by the Forestry Research Center in Arezzo (Italy) in mixed oak and chestnut coppices of central Italy. In the mixed coppices, the silvicultural objective was to differentiate the management and the timber assortments by maintaining the coppice system to produce valuable timber from sporadic tree species, selecting a few target trees per hectare and, through the conversion into high forest, creating favorable conditions for their growth and natural regeneration. Contrastingly, in chestnut coppices the goal was to obtain more valuable and larger-sized assortments in a shorter rotation period with lower costs.

\section{Materials and methods}

\section{The study areas}

The research was carried out in two important forest districts of Tuscany (Italy): Monte Amiata (Siena) and Colline Metallifere (Grosseto), which were characterized by a wide presence of coppices and an intense human pressure over the centuries (Fig. S1 in Supplementary material).

Monte Amiata is one of the most important areas in Italy for chestnut timber production due to its extension (3500 ha, 12.5\% of the total forest area), site quality and high productivity. Conversely, in the Colline Metallifere chestnut has a rather marginal role ( 1300 ha, $3 \%$ of total forest area), being mixed broadleaf forests ( 38400 ha $80 \%$ of forest area), where Turkey oak is the dominant species, largely prevailing.

Up to the half of the last century, both the districts were characterized by mines (mercury in Monte Amiata; pyrite, copper, lead and zinc in Colline Metallifere), which exploited wood products from local coppices. Later, the mining crisis gave rise to a discontinued use of many coppices for timber production. Currently, the forest area is rather fragmented (often in patches $<1 \mathrm{ha}$ ) and the private ownership is common in both districts ( $90 \%$ in the Colline Metallifere and $80 \%$ in the Amiata).

The chestnut coppice stands in Monte Amiata are located between 800 and 1200 $\mathrm{m}$ a.s.I. on a trachyte bedrock; the most common soil is Andic Dystrudepts coarseloamy, siliceous, mesic (unit GUA1 - http:// sit.lamma.rete.toscana.it/websuoli/), deep, soft, not gravel, not calcareous, acid, welldrained. The climate is mountain-Mediterranean, with an annual rainfall of $1547 \mathrm{~mm}$ concentrated in autumn and winter, and a mean annual temperature of $10{ }^{\circ} \mathrm{C}$ (Fig. S2 in Supplementary Material). Stand management differs depending on the property: in the public ownership the rotation time is $25-30$ years, with thinning at the mid of rotation and a low number of standards; in private ownership, the rotation time is about 16 years, no thinnings are carried out and more than 60 standards per hectare are released.

The study areas on the Colline Metallifere are located from 580 to $750 \mathrm{~m}$ a.s.l. on typic ustorthents loamy-skeletal, mixed, calcareous, mesic, shallow soils (unit CBO1) originated from sandstone and limestone. The climate is Mediterranean with mean annual temperature of $11.7{ }^{\circ} \mathrm{C}$ and annual rainfall of $1047 \mathrm{~mm}$ (Fig. S2 in the Supplementary material). The forest area is mainly managed as coppice (coppice with standards), though conversion into high forests has been locally carried out. The prevailing stand types are Turkey oak (Quercus Cerris L.) coppices and mixed broadleaved coppices with hop hornbeam (Ostrya Carpinifolia Scop.) and flowering ash (Fraxinus ornus L.); chestnut coppices show a smaller extension, but are an important resource for local population.

\section{Experimental trials}

Eleven sample plots (Tab. 1) were established in both districts ( 3 in Monte Amiata and 8 in the Colline Metallifere) with different dominant tree species (chestnut or Turkey oak), mixture degree (presence of sporadic or valuable tree species), age (from 11 to $48 \mathrm{yrs}$ ) and site quality (from medium to good).

In the chestnut coppices of both experimental areas, the impact of tree-oriented silvicultural practices (thesis A) was compared with the absence of management (thesis $C$ ) and with the standard stand silvicultural practices (thesis B), characterized by early and frequent thinnings from below (Amorini et al. 2000, Amorini \& Manetti 2002). In thesis A, 100 target trees per hectare were selected and crown thinning was carried out to make their crown completely isolated from the surrounding canopy. The thinning was focused only on stools, shoots and standards around the target trees, whereas no treatment was applied in the remaining stand. Target trees were selected according to tree vigor, stem features, crown shape, lack of

Tab. 1 - Main site characteristics and research structure of the analyzed study-cases.

\begin{tabular}{llllll}
\hline \multirow{2}{*}{ Characteristics } & Chestnut coppices & \multicolumn{5}{l}{ Mixed coppices } \\
\cline { 2 - 6 } & Monte Amiata & Colline Metallifere & Colline Metallifere & \\
\hline Age (yrs) & 18 & 24 & $13-15$ & 47 & 48 \\
Sample plots & 3 & 3 & 2 & 1 & 2 \\
Site quality & Good & Medium & Good - Medium & Good & Medium \\
Management goal & High quality timber & High quality timber & $\begin{array}{l}\text { Preserving and } \\
\text { enhancing biodiversity }\end{array}$ & $\begin{array}{l}\text { Preserving and } \\
\text { enhancing biodiversity }\end{array}$ & $\begin{array}{l}\text { Preserving } \\
\text { biodiversity }\end{array}$ \\
Experimental & (A) Tree-oriented & (A) Tree-oriented & A37 B18 - localized & A39- localized & (A) Tree-oriented \\
thesis & silviculture; (B) Stand & silviculture; (B) Stand & thinning from above & thinning from above & silviculture; (B) \\
& silviculture; (C) control & silviculture; (C) control around sporadic tree & around sporadic tree & Stand silviculture \\
& & & species & species & \\
Altitude (m a.s.l.) & 990 & 720 & $740-580$ & 750 & 590 \\
Exposure & S-SE & N-NW & NW - NE & NW & S \\
Slope (\%) & 10 & 20 & $18-25$ & 40 & 22 \\
\hline
\end{tabular}


disease symptoms (e.g., chestnut blight) and their spatial distribution. In both $A$ and $B$ stands, the first thinning was carried out early (11 yrs in Amiata and 17 yrs in Metallifere). However, a second thinning has been carried out three years later only in A stands of both districts, to ensure crown isolation for target trees.

Mixed coppices were analyzed only in the Colline Metallifere district, considering two different study-case: (i) young coppices ( $\mathrm{A} 37$ and $\mathrm{B} 18$ ) where the management goal was to maintain the coppice system to preserve and enhance biodiversity; (ii) aged coppices (A39, FA and FB) where the conversion into high forest was carried out to preserve tree biodiversity. The plots have been chosen for their relatively high abundance of sporadic species, for suitable site conditions, good trail density to avoid excessive costs. In young coppices (i), the traditional management approach (clear cutting at 25-30 years) was integrated with the tree-oriented silvicultural practices: 520 sporadic tree species ha ${ }^{-1}$ were selected and favored by localized thinning at 13-15 yrs. Tree competitors around the target trees were removed and a buffer free space of 1-3 $\mathrm{m}$ (dètourage) was created to allow the free development of the crown.

In the aged coppices (ii), thesis A (treeoriented silviculture) was applied in plot FA and compared with plot FB where thesis $B$ was applied. During the second thinning in 2007 (at the age of 44 years in FA), 144 target trees were selected both in the dominant layer and among sporadic tree species, and their closer competitors were removed by thinning from above. The same number of crop trees were chosen in $\mathrm{FB}$, but a thinning from below was carried out, reducing tree density by $39 \%$.

Mixed coppiced were particularly rich of sporadic tree species, mainly wilde service tree Sorbus torminalis (L) Crantz. Therefore, tree-oriented silviculture was applied to stands with different ages (the aged coppice A39, 47 years old; and the young
Tab. 2 - Statistics of the current annual increment (CAI dbh) of crop trees in the studied plots. (STD): standard deviation; (Qc); Quercus cerris; (St): Sorbus torminalis.

\begin{tabular}{lllllllll}
\hline $\begin{array}{l}\text { Coppice } \\
\text { Type }\end{array}$ & Area & $\begin{array}{l}\text { Other } \\
\text { species }\end{array}$ & Plot & Obs & Mean & STD & Min & Max \\
\hline Chestnut & Monte & - & A & 23 & 8.2 & 1.6 & 4.8 & 12.4 \\
& Amiata & - & B & 24 & 4.5 & 1.9 & 2.1 & 8.6 \\
& & - & C & 24 & 2.6 & 0.7 & 1.1 & 3.9 \\
& Colline & - & A & 26 & 5.1 & 1.4 & 2.8 & 8.0 \\
& Metallifere & - & B & 25 & 3.3 & 0.8 & 1.5 & 5.7 \\
\multirow{2}{*}{ Mixed } & Colline & QC & FA & 34 & 0.3 & 0.1 & 0.1 & 0.7 \\
& Metallifere & & FB & 35 & 0.3 & 0.1 & 0.2 & 0.5 \\
\cline { 3 - 8 } & & St & A39 & 52 & 0.4 & 0.2 & 0.0 & 0.8 \\
& & & A37 & 44 & 0.6 & 0.3 & 0.0 & 1.2 \\
\hline
\end{tabular}

coppice $A 37,15$ years old) to verify the effect of the same treatment on tree growth in stands characterized by different age, density, and stools height.

\section{Data collection and analysis}

In all experimental plots, the species, the diameter at breast height (dbh), the total tree height $(\mathrm{H})$ and the social rank of trees were measured before (BT) and after thinning (AT) since 2008 to 2014. In chestnut coppices, crown development was estimated based on the measure of four orthogonal radii and the main canopy cover characteristics (Leaf Area Index - LAl and transmittance - PAR) was monitored.

For each plot, the following stand parameters were calculated before and after the thinning: site quality (through the dominant height), stand density (number of stools, shoots and standards), productivity (basal area and volume), species composition (number of species, Shannon index Shannon 1948), importance value (average of relative density and relative basal area of the considered species or layer - Chapman et al. 2006). The canopy cover was assessed by measuring the LAl (using a LAI2000 instrument - Li-Cor, Linkoln, NE, USA) and PAR (AccuPAR Ceptometer Decagon, Pullman, WA, USA) according to

\section{Cutini (2001) and Bréda (2003).}

To allow the comparison of the different silvicultural options, an equivalent number of target trees (chosen among the largest trees of the stands) was considered in the analysis for all the three thesis (A, B, C). For all the target trees, several additional parameters (height at the crown base, crown area and stem quality) were recorded.

Differences among the three thesis were assessed at individual (crop trees) and stand level by comparing the current annual increment in diameter (Tab. 2) and the crown growth of the target trees, as well as the stand biodiversity. Differences in current annual increment in $\mathrm{dbh}(\mathrm{CAl})$ and periodical increment $(\mathrm{PI})$ were tested through the analysis of variance (ANOVA), and compared by the post-hoc Tukey's ttest. All analyses were carried out using the R package (http://www.r-project.org/).

\section{Results}

\section{Stand characteristics and thinning}

\section{Chestnut coppices}

The structural, ecological and stand parameters recorded before thinning (Tab. 3) revealed the suitability of the selected chestnut coppices in both districts for the

Tab. 3 - Chestnut coppices in Monte Amiata (A) and Colline Metallifere (M). Mensurational parameters, tree diversity and importance value in the study areas before thinning occurrence. (a): Tree-oriented silviculture (b): stand silviculture; (c): control.

\begin{tabular}{|c|c|c|c|c|c|c|c|}
\hline \multicolumn{2}{|c|}{ Study area } & $\mathrm{Aa}$ & $A b$ & Ac & $\mathrm{Ma}$ & $M b$ & Mc \\
\hline \multicolumn{2}{|c|}{ Year of the thinning } & 2007 & 2007 & 2007 & 2008 & 2008 & 2008 \\
\hline \multicolumn{2}{|c|}{ Age (years) } & 11 & 11 & 11 & 17 & 17 & 17 \\
\hline \multicolumn{2}{|c|}{ Dominant height (m) } & 13.2 & 13.0 & 13.1 & 15.4 & 15.4 & 15.5 \\
\hline Number & Stools & 968 & 800 & 736 & 1324 & 888 & 943 \\
\hline \multirow[t]{3}{*}{ (n ha-1) } & Shoots & 6012 & 5972 & 5708 & 3588 & 2668 & 2449 \\
\hline & Standards & 84 & 68 & 88 & 68 & 72 & 64 \\
\hline & Total & 6096 & 6040 & 5796 & 3656 & 2740 & 2513 \\
\hline Basal area & Shoots & 25.71 & 23.49 & 23.43 & 29.55 & 22.80 & 18.23 \\
\hline \multirow[t]{2}{*}{$\left(\mathrm{m}^{2} \mathrm{ha-}-1\right)$} & Standards & 6.74 & 7.07 & 7.18 & 2.43 & 3.98 & 5.29 \\
\hline & Total & 32.45 & 30.56 & 30.61 & 31.98 & 26.78 & 23.52 \\
\hline \multirow{2}{*}{ DBH $(\mathrm{cm})$} & Shoots & 7.4 & 7.1 & 7.2 & 10.2 & 10.4 & 9.7 \\
\hline & Standards & 32.0 & 36.4 & 32.2 & 21.3 & 26.5 & 32.4 \\
\hline \multirow[t]{2}{*}{ Tree diversity } & Shannon index & 0.00 & 0.00 & 0.00 & 0.88 & 1.01 & 1.20 \\
\hline & Number of species & 1 & 1 & 1 & 7 & 7 & 6 \\
\hline \multirow{2}{*}{$\begin{array}{l}\text { Importance } \\
\text { value (\%) }\end{array}$} & Chestnut & 100 & 100 & 100 & 80 & 82 & 72 \\
\hline & Dominant layer & 44 & 39 & 44 & 37 & 46 & 50 \\
\hline \multirow{2}{*}{$\begin{array}{l}\text { Canopy } \\
\text { characteristics }\end{array}$} & $\operatorname{LAl}\left(\mathrm{m}^{2} \mathrm{~m}^{2}\right)$ & 6.28 & 5.61 & 6.31 & 5.3 & 5.1 & 5.2 \\
\hline & Transmittance (\%) & 1.75 & 1.52 & 1.38 & 3.5 & 3.6 & 3.4 \\
\hline
\end{tabular}


Tab. 4 - Chestnut coppices. Number of selected target trees, thinning intensities and characteristics (I th: first thinning in thesis $A$ and $B$, simultaneously; II th: second thinning only in thesis A) carried out in chestnut coppices managed under the two theses (A: tree-oriented silviculture; B: stand silviculture) in Monte Amiata and Colline Metallifere. (Cs): Castanea sativa; (Qc): Quercus cerris.

\begin{tabular}{|c|c|c|c|c|c|c|}
\hline \multirow{2}{*}{ Parameter } & \multirow{2}{*}{$\begin{array}{c}\text { Amiata } \\
\text { Al th }\end{array}$} & \multicolumn{5}{|c|}{ Metallifere } \\
\hline & & A II th & B I th & A I th & A II th & B I th \\
\hline Target trees (n ha- ${ }^{-1}$ ) & 96 & 96 & 96 & 100 & 100 & 100 \\
\hline Age of thinning & 11 & 14 & 11 & 17 & 20 & 17 \\
\hline Removed trees (n ha- ${ }^{1}$ ) & 1444 & 1124 & 3592 & 1320 & 340 & 1508 \\
\hline \multirow{2}{*}{$\%$ per species } & $100 \mathrm{Cs}$ & $100 \mathrm{Cs}$ & $100 \mathrm{Cs}$ & $80 \mathrm{Cs}$ & 77 Cs & $85 \mathrm{Cs}$ \\
\hline & - & - & - & $18 \mathrm{Qc}$ & 20 Qc & $8 \mathrm{QC}$ \\
\hline Removed BA ( $\mathrm{m}^{2}$ ha-1) & 10.06 & 8.39 & 13.61 & 12.58 & 4.31 & 10.43 \\
\hline \multirow[t]{2}{*}{$\%$ per species } & $100 \mathrm{Cs}$ & $100 \mathrm{Cs}$ & $100 \mathrm{Cs}$ & $76 \mathrm{Cs}$ & $81 \mathrm{Cs}$ & $89 \mathrm{Cs}$ \\
\hline & - & - & - & $22 \mathrm{Qc}$ & $18 \mathrm{QC}$ & $6 \mathrm{Qc}$ \\
\hline $\mathrm{N}(\%)$ & 24.0 & 29.0 & 59.0 & 36.1 & 16.9 & 55.0 \\
\hline BA (\%) & 31.0 & 29.0 & 45.0 & 39.3 & 19.0 & 38.9 \\
\hline $\mathrm{DBH}(\mathrm{cm})$ & 9.4 & 9.7 & 6.9 & 11.0 & 12.7 & 9.4 \\
\hline
\end{tabular}

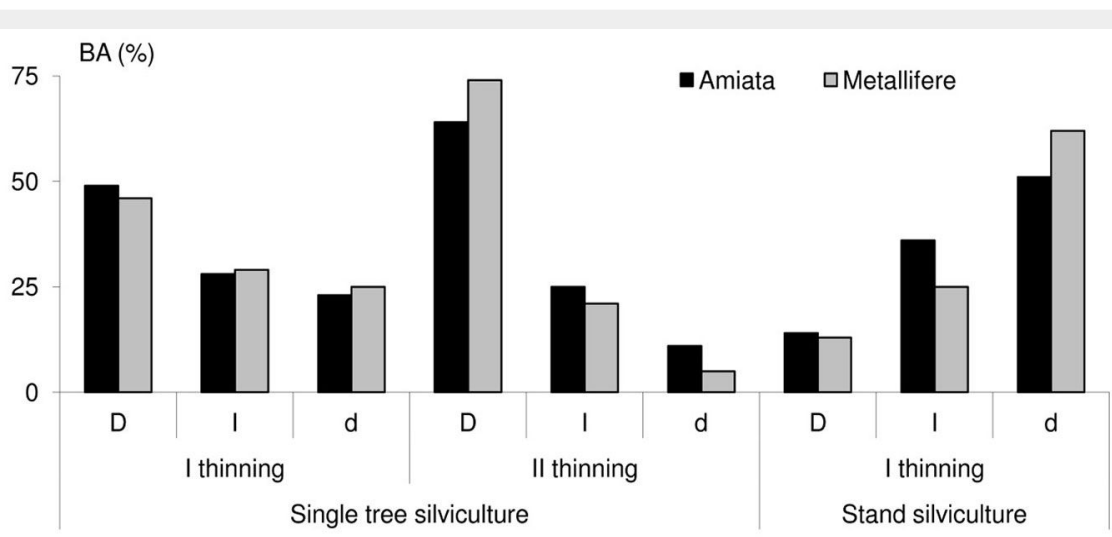

Fig. 1 - Percentage of basal area (BA) removed by thinning per social class in chestnut coppices managed under the two thesis (A: single-tree silviculture; B: stand silviculture) in the two districts analyzed (Amiata and Metallifere). (D): dominant; (I): intermediate; (d): dominated.

application of a silvicultural approach aimed at producing high quality timber assortments. The stands in both areas showed good site quality, adequate number of stools, high productivity, a well-defined dominant layer and proper values of LAl (6.07 and 5.40 in Monte Amiata and Colline Metallifere, respectively) and PAR (1.68 and 4.51 , respectively - Cutini \& Fabbio tallifere).

1997). The main differences were related In the studied chestnut coppices, the to the age of the first thinning (11 years in thinning carried out in the two thesis (A: Monte Amiata and 17 years in Colline Met- from above; B: from below) was characterallifere) and the species composition (pure ized by different frequency and intensity chestnut in Monte Amiata, while up to 20\% (Tab. 4), resulting from differences in the in number and $15 \%$ in basal area of other social rank of the harvested trees (Fig. 1). species - mainly Turkey oak - in Colline Me- In both districts, an additional thinning

Tab. 5 - Structural parameters, tree diversity and importance value in mixed coppice plots before thinning in the Colline Metallifere. (Qc): Quercus cerris; (Qp): Q. petraea; (Qcr): Q. crenata; (Qi): Q. ilex; (Fo): Fraxinus ornus; (Ac): Acer campestre; (At): A. monspessulanum; (Oc): Ostrya carpinifolia; (la): Ilex aquifolium; (Jc): Juniperus communis; (Ms): Malus sylvestris; (Cm): Cornus mas; (Um): Ulmus campestris; (St): Sorbus torminalis; (Sd): S. domestica; (Pp): Pyrus pyraster.

\begin{tabular}{|c|c|c|c|c|c|c|}
\hline \multicolumn{2}{|l|}{ Parameter } & B18 & A37 & A39 & FA & FB \\
\hline \multicolumn{2}{|c|}{ Year of the thinning } & 2011 & 2011 & 2011 & 2007 & 2007 \\
\hline \multicolumn{2}{|c|}{ Age (years) } & 13 & 15 & 47 & 44 & 44 \\
\hline \multicolumn{2}{|c|}{ Dominant height (m) } & 9.8 & 14.9 & 17.1 & 15.7 & 17.2 \\
\hline Number & Stools & 1700 & 1201 & 1823 & 1363 & 1450 \\
\hline \multirow{3}{*}{$(\mathrm{n} \mathrm{ha-1)}$} & Shoots & 2809 & 5111 & 2926 & 1500 & 1494 \\
\hline & Standards & 64 & 181 & 206 & 109 & 84 \\
\hline & Total & 2873 & 5292 & 3132 & 1609 & 1578 \\
\hline \multirow{3}{*}{$\begin{array}{l}\text { Basal area } \\
\left(\mathrm{m}^{2} \mathrm{ha}^{-1}\right)\end{array}$} & Shoots & 10.27 & 11.01 & 25.97 & 20.26 & 20.58 \\
\hline & Standards & 1.57 & 5.92 & 7.85 & 3.27 & 2.33 \\
\hline & Total & 11.84 & 16.93 & 33.82 & 23.53 & 22.91 \\
\hline \multirow[t]{2}{*}{$\mathrm{DBH}(\mathrm{cm})$} & Shoots & 6.8 & 5.1 & 10.6 & 13.1 & 13.2 \\
\hline & Standards & 17.7 & 20.4 & 22.0 & 19.5 & 18.8 \\
\hline \multirow[t]{2}{*}{ Tree diversity } & Shannon index & 0.51 & 1.48 & 1.69 & 1.12 & 0.85 \\
\hline & Number of species & 6 & 6 & 6 & 13 & 12 \\
\hline & Main species & 93 & 94 & 93 & 88 & 92 \\
\hline (\%) & Secondary species & 6 & 1 & 1 & 7 & 4 \\
\hline \multirow{2}{*}{ Tree species } & Secondary species & Qp Fo & Qp Ac & Ac la & $\begin{array}{l}\text { Qp Jc Ms Fo Ac } \\
\text { At Cm la Um }\end{array}$ & $\begin{array}{l}\text { Qp Jc Ms Fo } \\
\text { Ac Qcr Qi la }\end{array}$ \\
\hline & Valuable species & St Sd Pp & St & St & St Sd Pp & St Sd Pp \\
\hline
\end{tabular}


Tab. 6 - Number of selected target trees, thinning intensities and characteristics of the mixed coppice plots in the Metallifere district. (Qc): Quercus cerris; (Qp): Q. petraea; (Qcr): Q. crenata; (Qi): Q. ilex; (Fo): Fraxinus ornus; (Ac): Acer campestre; (At): A. monspessulanum; (Oc): Ostrya carpinifolia; (la): Ilex aquifolium; (Jc): Juniperus communis; (Ms): Malus sylvestris; (Cm): Cornus mas; (Um): Ulmus campestris; (St): Sorbus torminalis; (Sd): S. domestica; (Pp): Pyrus pyraster.

\begin{tabular}{|c|c|c|c|c|c|}
\hline Parameter & B18 & A37 & A39 & FA & FB \\
\hline $\begin{array}{l}\text { Target trees }\left(\mathrm{n} \mathrm{ha}{ }^{-1}\right) \\
\text { Valuable species } \\
\text { Other species }\end{array}$ & $\begin{array}{c}19 \\
13 \mathrm{Sd} \\
\mathrm{QC}\end{array}$ & $\begin{array}{c}28 \\
28 \mathrm{St} \\
\text { Qc Fo la }\end{array}$ & $\begin{array}{c}41 \\
23 \mathrm{St} \\
\text { Qc Qp Fo Ac Um }\end{array}$ & $\begin{array}{c}144 \\
13 \text { Sd, } 3 \text { St } \\
\text { Qc Fo }\end{array}$ & $\begin{array}{c}146 \\
29 \mathrm{Sd}\end{array}$ \\
\hline $\begin{array}{l}\text { Removed trees }\left(\mathrm{n} \mathrm{ha}^{-1}\right) \\
\% \text { per species }\end{array}$ & $\begin{array}{l}160 \\
88 \mathrm{QC} \\
12 \mathrm{Fo} \\
-\end{array}$ & $\begin{array}{c}368 \\
13 \mathrm{Qc} \\
53 \mathrm{Oc}, 28 \mathrm{Fo} \\
6 \mathrm{St}\end{array}$ & $\begin{array}{c}246 \\
46 \mathrm{Qc} \\
28 \mathrm{Oc}, 22 \mathrm{Fo} \\
4 \mathrm{St}\end{array}$ & $\begin{array}{c}437 \\
94 \mathrm{Qc} \\
4 \mathrm{Qp}+\mathrm{Fo} \\
2 \mathrm{Pp}+\mathrm{St}\end{array}$ & $\begin{array}{c}606 \\
97 \mathrm{Qc} \\
3 \mathrm{Qp}+J c+Q i \\
-\end{array}$ \\
\hline $\begin{array}{l}\mathrm{N}(\%) \\
\mathrm{BA}(\%) \\
\mathrm{DBH}(\mathrm{cm})\end{array}$ & $\begin{array}{l}5.6 \\
4.8 \\
6.7\end{array}$ & $\begin{array}{l}7.0 \\
8.3 \\
7.0\end{array}$ & $\begin{array}{r}7.8 \\
9.5 \\
12.9\end{array}$ & $\begin{array}{l}27.2 \\
29.5 \\
14.2\end{array}$ & $\begin{array}{l}38.4 \\
32.3 \\
12.5\end{array}$ \\
\hline
\end{tabular}

after three years was necessary in thesis $A$ to ensure the crown isolation of the target trees. However, the faster canopy recover observed in the Monte Amiata required a larger tree removal as compared with the Colline Metallifere stands, likely due to the higher site fertility and the younger age of trees at the former site. Overall, considering the two thinnings, the basal area removed was higher in the thesis $A$ than in $B$ for both districts (Tab. 4).

\section{Mixed coppices}

The main stand parameters recorded in the study areas before thinning are reported in Tab. 5. The young mixed coppices (B18 and A37) showed different values of dominant height, density and productivity, which were much more higher in $\mathrm{A} 37$ than $\mathrm{B} 18$, as well as the tree biodiversity (Shannon index $=1.48$ and 0.51 in $A 37$ and $B 18$, respectively).

The studied aged coppices (A39, FA and $\mathrm{FB}$ ) had similar values for most parameters, except site quality (which was lower in FA) and the stand density and productivity (higher in A39). As for species composition, the number of sporadic and valuable tree species was higher in FA (13) and FB (12), while Shannon index was higher (1.69) in A39 than in FA and FB (1.12 and 0.85, respectively). Sorbus spp. was the most important sporadic species in all analyzed plots.

In the plots B18, A37 and A39 the applied silvicultural practices were aimed at enhancing biodiversity and improving timber quality of sporadic species, while conversion into high forest was carried out according to tree-oriented silviculture in FA and stand silviculture in FB. In the first case, thinning intensity was lower (Tab. 6) as harvesting was carried out mainly around the target trees. In B18 the thinning affected almost exclusively Turkey oak ( $91 \%$ of removed basal area), while in the other two areas (A37 e A39), also other species (34\% in $\mathrm{A} 37$ and $31 \%$ in $\mathrm{A} 33$ ) and some valuable tree species ( $7 \%$ in $\mathrm{A} 37$ and $2 \%$ in $\mathrm{A} 33$ ) were removed.

In FA and FB stands, a first thinning from below was carried out in 2001 by the Forest Municipality, before the establishment of the experimental plots. In 2007, 144 target trees per hectare, chosen among the most vigorous Turkey oaks and valuable sporadic species, were selected in both FA and FB plots to verify the growth differences after the silvicultural approach applied. In both areas, thinning involved almost exclusively Turkey oak and the dominant layer $(81 \%$ in FA and $68 \%$ in FB), which represented $80 \%$ of the basal area before thinning. The treeoriented practices applied mainly impacted the dominant layer, thus the mean diameter of removed shoots was higher (14.2 vs.
12.5), despite a lower thinning intensity in terms of basal area (Tab. 6).

\section{Chestnut coppices}

\section{Growth performances}

ANOVA results based on current annual increment (CAl) of selected (target) trees collected before the first thinning did not reveal significant differences among theses (A vs. B and C) and districts (Monte Amiata, Colline Metallifere). In contrast, significantly higher CAls of the target trees after thinning was observed in all thesis. As expected, such increments were much higher for thesis A, where the target shoots were completely isolated and the competition

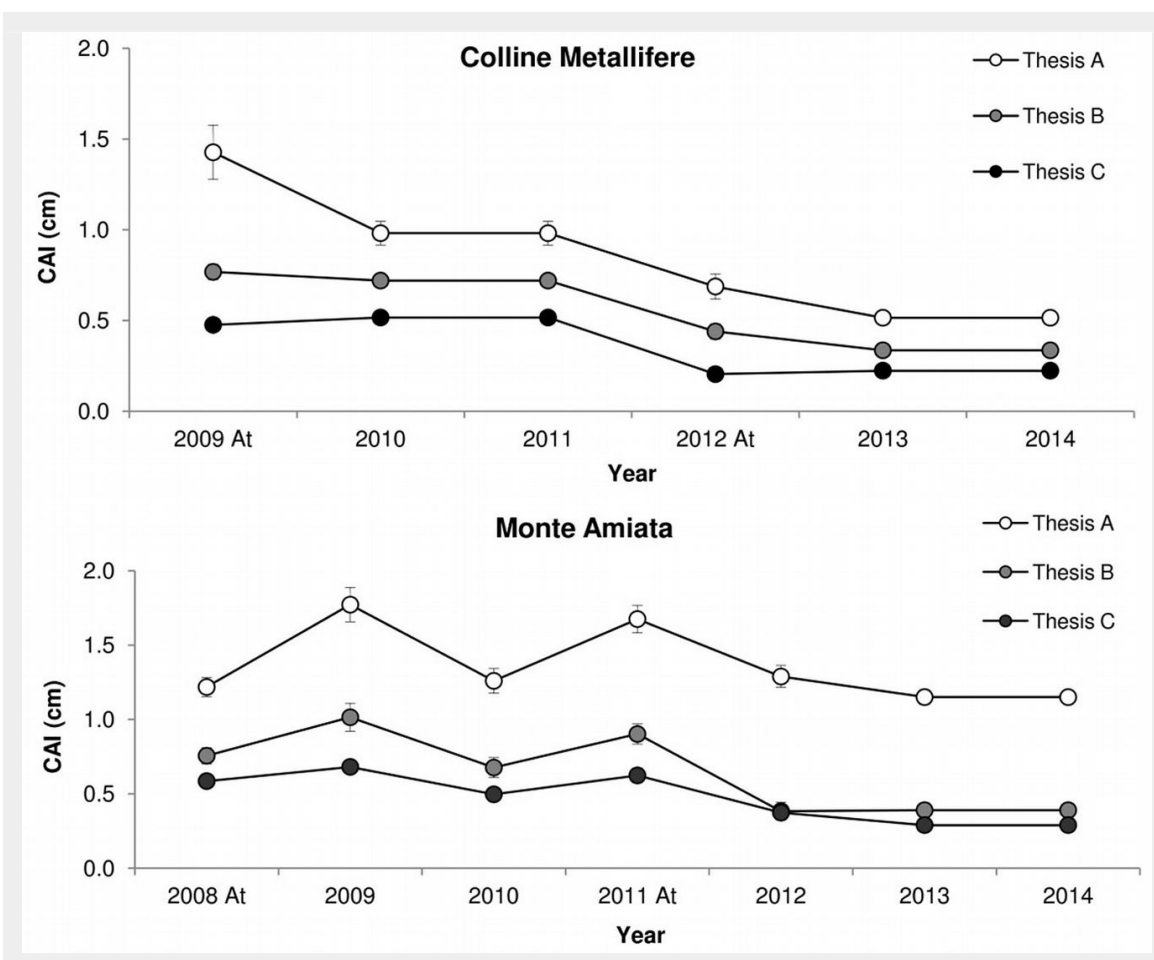

Fig. 2 - Trends of current annual increment (CAI) in diameter at breast height ( \pm standard error) of the chestnut target trees in the three theses (A, B, C: different silvicultural approaches) in the two districts analyzed. (At): after thinning. 

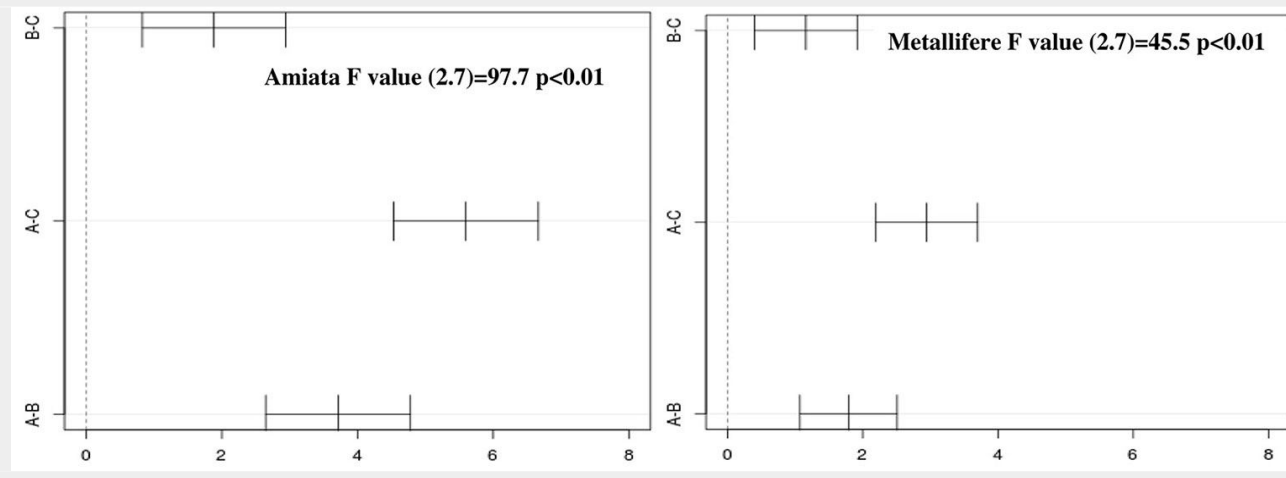

Fig. 3 - Analysis of variance and results of the Tukey's test for multiple comparisons of periodic increment in diameter $\left(\mathrm{PI}_{\mathrm{dbh}}\right)$ of the chestnut target trees between the three theses ( $A, B, C$ : different silvicultural approaches) in the two districts analyzed (Amiata e Metallifere). reduced (Fig. 2). In Monte Amiata, the growth rate resulted fairly constant over time as a consequence of the two thinnings carried out, while in the Colline Metallifere the trend was slowly decreasing. In this case, such negative response to thinning can be attributed to various causes (e.g., low intensity of thinning, stand age, stand fertility, seasonal climatic trend, etc). In addition, the presence of the gall wasp (Dryocosmus kuriphilus Yasu-

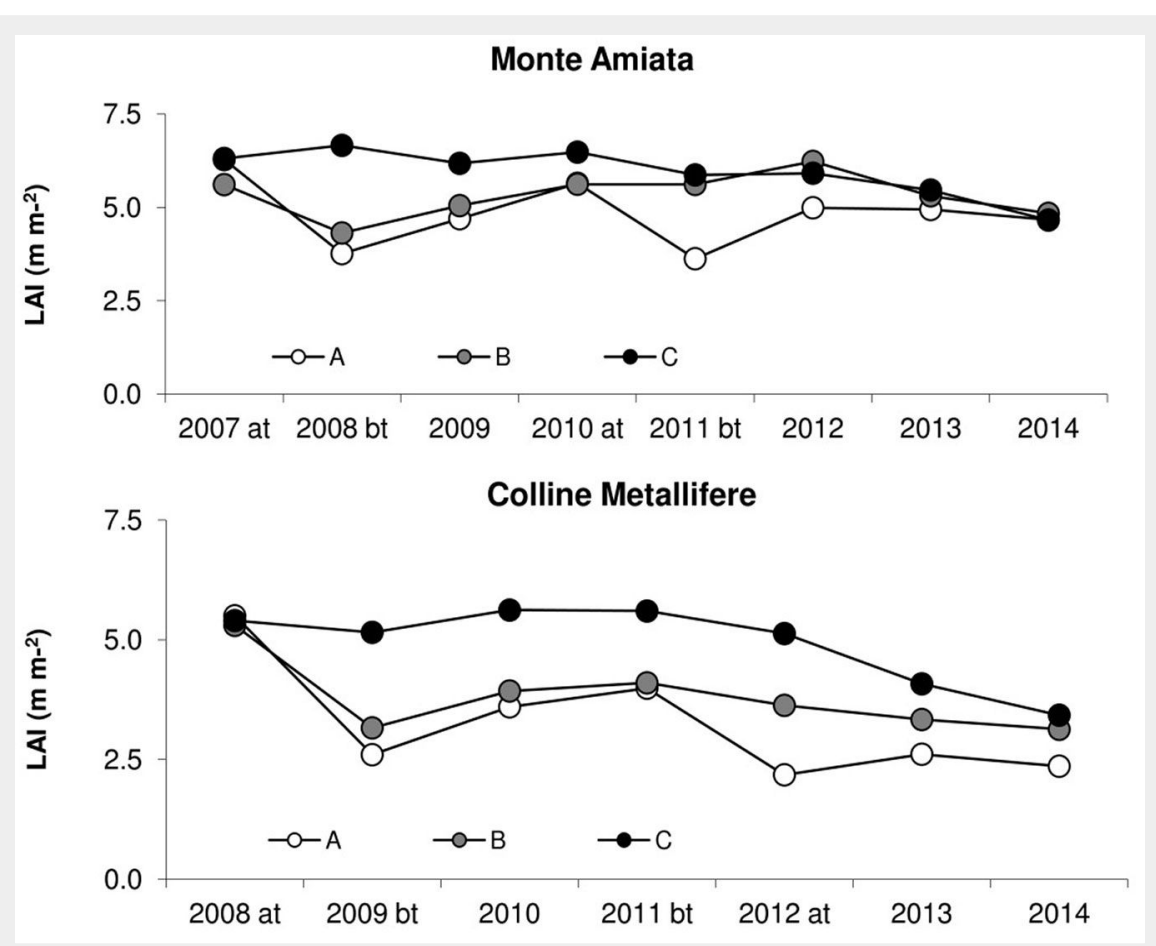

Fig. 4 - Mean annual LAl values recorded in chestnut coppice plots managed under the three thesis ( $A, B, C$ : different silvicultural approaches) in the two districts analyzed. (at): after thinning; (bt): before thinning.

Tab. 7 - Mean periodic increment of crown radius (in $\mathrm{m}, \pm$ standard error) of the selected target trees in chestnut coppices and differences among the three theses in Monte Amiata and Colline Metallifere. (A): tree-oriented silviculture; (B): stand silviculture; $(C)$ : control. Different lowercase letters indicate significant differences between means after Tukey's test $(p<0.05)$.

\begin{tabular}{lcc}
\hline Thesis & Amiata & Metallifere \\
\hline A & $0.72 \pm 0.06^{\text {a }}$ & $0.54 \pm 0.05^{\mathrm{a}}$ \\
B & $0.26 \pm 0.04^{\mathrm{b}}$ & $0.26 \pm 0.05^{\mathrm{b}}$ \\
C & $0.23 \pm 0.05^{\mathrm{b}}$ & $0.11 \pm 0.03^{\mathrm{c}}$ \\
\hline
\end{tabular}

increments $(\mathrm{PI})$ among the three silvicultural options over the whole period of observation (6 years in Metallifere and 7 years in Amiata). For both districts, the larger difference in diameter $\mathrm{Pl}$ was recorded between the thesis $\mathrm{A}$ (characterized by two closed thinnings) and control plots (C), while the smaller was between $C$ and $B$ stands, where only one thinning was applied during the study period.

\section{Canopy characteristics}

Annual LAI values reflected the stand capacity to restore canopy cover under the different silvicultural options (Fig. 4). Before thinning, LAl was 6.7 and 5.5 in Amiata and Metallifere, respectively, indicating a good level of stand functionality with respect to the stand age in both district. In the first year after thinning LAI values decreased significantly in thesis $A$ and $B$ (depending on thinning intensities); however, the differences tend to disappear in short time (2-4 years, depending on stand age). The effect on LAl of second thinning carried out in thesis A showed the same pattern.

The periodic increment of crown radius $\left(\mathrm{PI}_{\mathrm{cr}}\right)$ recorded in the three years after the first thinning, reflected the good reaction of the selected trees under the tree-oriented silvicultural approach on both sites (Tab. 7). In Monte Amiata (younger and more fertile stands), $\mathrm{Pl}_{\mathrm{cr}}$ mean values were three times higher in the option $\mathrm{A}(0.72 \mathrm{~m})$ than in the other two options, and no significant differences have been observed between $\mathrm{B}(0.26 \mathrm{~m})$ and control plot $(0.23$ $\mathrm{m}$ ) in this first period. Similar differences were observed in the Colline Metallifere, but the values were lower according to the adopted silvicultural system $(A=0.54 ; B=$ $0.26 ; C=0.11$ ).

\section{Mixed coppices}

\section{Tree biodiversity}

In young coppices the highest biodiversity values were observed in A37, also characterized by the highest fertility. Thinning did not seem to affect species composition and dynamics in the two plots (Fig. 5). In aged coppices, the differences detected in Shannon index values were likely due to stand density (as in the plot A39, character- 
Fig. 5 - Shannon index (SH) before (BT) and after (AT) the thinning carried out in mixed coppice plots. Values after seven years from thinning (white bars) were recorded only for FA and FB plots.

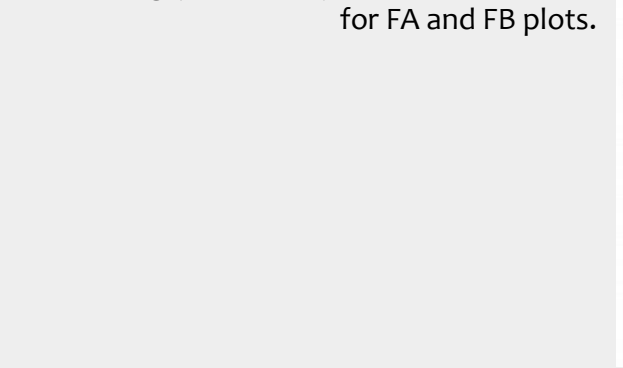

ized by the highest values of biodiversity) and to stand fertility (as in the plot FA, with higher dominant height values than FB). In the latter plots, the biodiversity increased after thinning, independently from the silvicultural option applied, and remained steady through time.

\section{Growth performances}

In the plots managed to enhance the presence of valuable tree species (plots A39, A37 and B18), 171 target trees in 23.47 hectares belonging to 7 different species were selected to assess the incremental response to thinning and crown isolation. As expected, CAI increased for all target trees of all the observed species, independently from stand age and site fertility (Fig. 6).

Significant differences in CAl dbh of wild tree service (the most important valuable species present in the forest district) were also found between plots $\mathrm{A} 39$ and $\mathrm{A} 37$ by ANOVA and Tukey's t-test (Fig. 7). Such differences turned out to be significant both before (2011) and after three years since thinning (2014), and can be mainly attributed to stand age, size of competitors, and thinning intensity, while the dimension of the selected crop trees and site fertility where similar in the two theses.

In the areas under conversion into high forest (FA and FB), no significant differences in CAl were observed 7 years after thinning among the two treatment applied (tree-oriented silviculture option, FA; stand silviculture option, FB - Tab. 8). However, FA had mean CAI values higher than FB

Fig. 7 - Analysis of variance and resuts of the Tukey's test for multiple comparisons among means of current annual increment in diameter $\left(\mathrm{cm} \mathrm{yr}^{-1}\right)$ of the selected wild service trees in mixed coppices managed under the two silvicultural options (A37, A39), at the beginning of the experiment $(a, 2011)$ and 3 years after thinning (b, 2014).

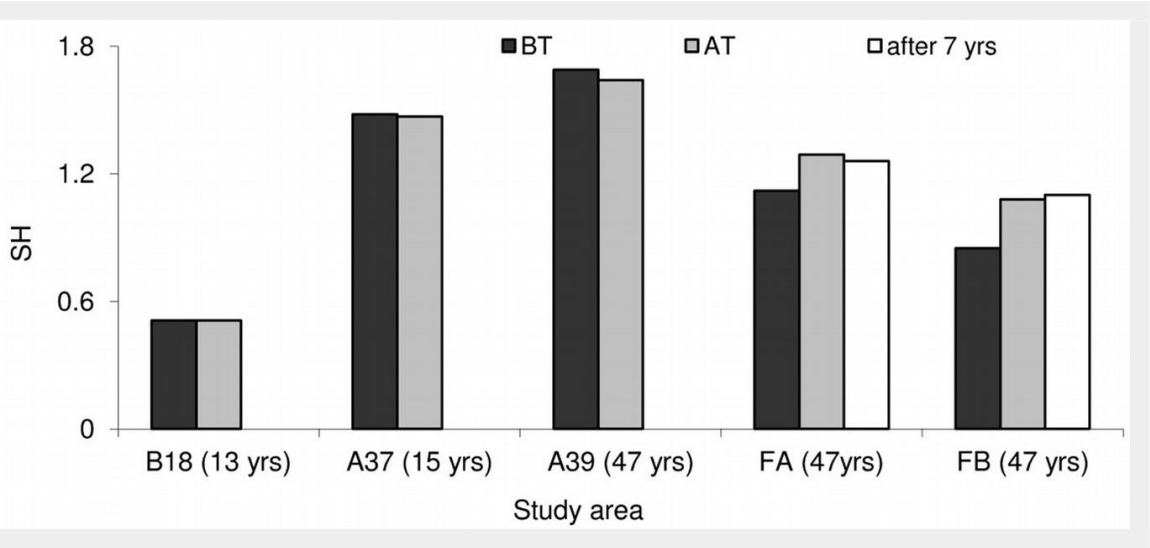

1,6

है
है 0,8
巡

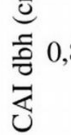

0
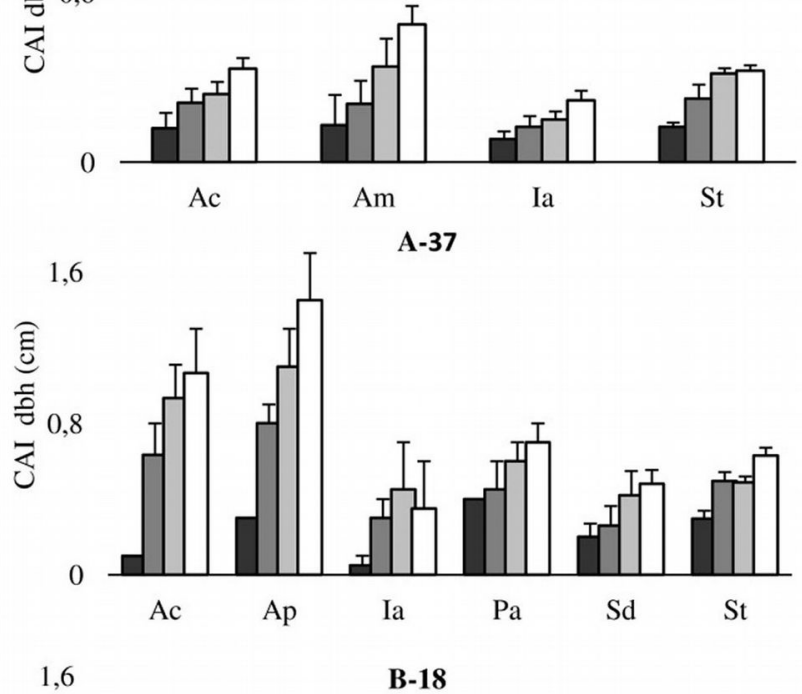

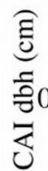

0

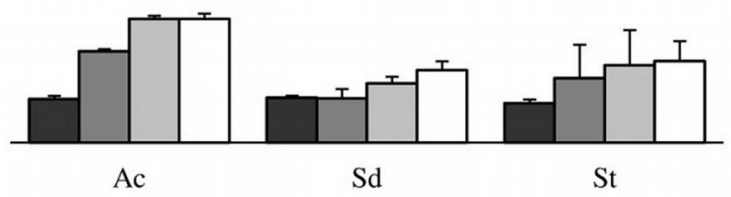

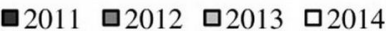

Fig. 6 - Mean current annual increment in diameter (CAl dbh, in $\mathrm{cm} \mathrm{yr}^{-1}$ ) of the selected target trees in the mixed coppices plots (A39, A37, B18), according to their species. Error bars represent the standard error. (Ac): Acer campestre; (Am): Acer monspessulanum; (Ap): Acer pseudoplatanus;

(la): Ilex aquifolium;

(Pa): Prunus avium;

(Sd): S. domestica;

(St): Sorbus torminalis.

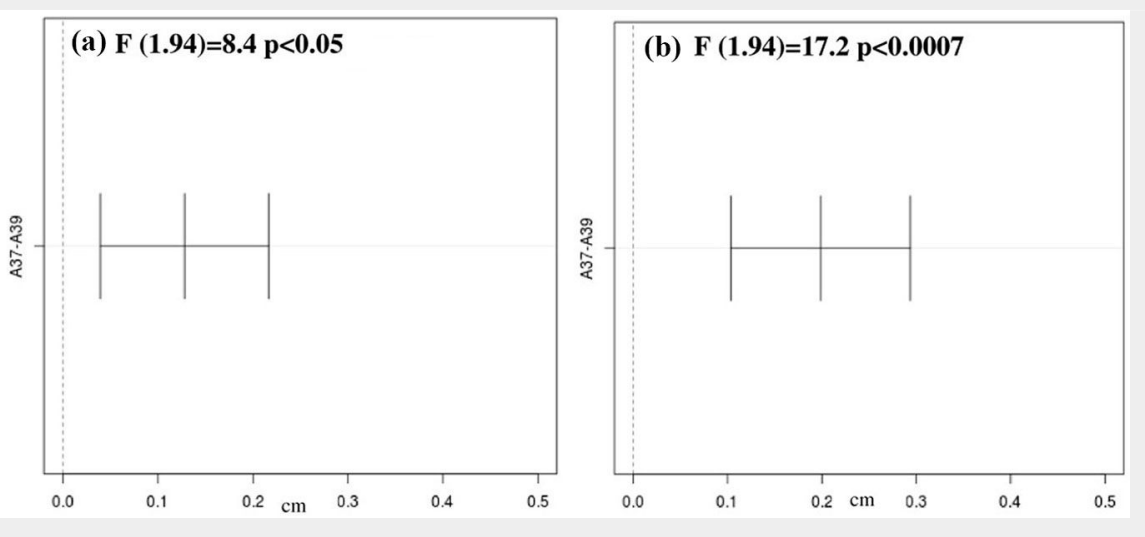


Tab. 8 - Stand dynamics of the aged mixed coppices under conversion into high forest, 7 years after thinning. $(\mathrm{M})$ : mortality rate; $(\mathrm{CAI})$ : current annual increment; $(\mathrm{BA})$ : basal area; (DBH): diameter at breast height; (FA): tree-oriented silviculture applied; (FB): stand silviculture applied; (Qc): Quercus cerris; (Fo): Fraxinus ornus; (Sd): Sorbus domestica.

\begin{tabular}{lll}
\hline Parameter & FA & FB \\
\hline$M(\%)$ & 2 & 1 \\
CAl BA $\left(\mathrm{m}^{2} \mathrm{ha}^{-1} \mathrm{yr}^{-1}\right)$ & 0.87 & 0.78 \\
CAI DBH Qc $\left(\mathrm{cm} \mathrm{yr}^{-1}\right)$ & 0.34 & 0.34 \\
CAI DBH Fo $\left(\mathrm{cm} \mathrm{yr}^{-1}\right)$ & 0.33 & 0.22 \\
CAl DBH Sd $\left(\mathrm{cm} \mathrm{yr}^{-1}\right)$ & 0.22 & 0.15 \\
\hline
\end{tabular}

both overall ( 0.87 vs. $\left.0.78 \mathrm{~m}^{2} \mathrm{ha}^{-1} \mathrm{yr}^{-1}\right)$ and for each of the target species considered (turkey oak, flowering ash and wild service tree). Both plots showed low mortality rate and an almost complete recover of the canopy 7 years after the thinning.

\section{Discussion and conclusions}

In this study, tree-oriented silviculture practices applied to coppice have proved to increase the growth of selected target trees as well as the stand biodiversity in terms of valuable timber preservation and production.

\section{Chestnut coppices}

In chestnut coppices the main goal of the practices applied was the improvement of valuable timber production. In this context, the observed tree growth and the recovery of biomass and canopy cover clearly demonstrated the suitability of the tree-oriented silvicultural approach applied to chestnut coppice (Manetti et al. 2014). Moreover, the early selection of a limited number of target trees (50-100 trees ha-1), to be favored along the whole rotation period through thinning, led to an increase in the complexity of the stands. Indeed, such management type promoted the presence in close proximity within the same stand of different vertical and horizontal structures (unmanaged coppice, isolated trees and thinned stools). Irregular stand structures are currently considered to improve the environmental value at the landscape level (Oliver \& Larson 1996, Spiecker 2003, Chapman et al. 2006).

In both silvicultural approaches (A: treeoriented silvicultural option; B: stand silvicultural option) thinning should be applied early (10-15 years) to allow the improvement of both stem quality and crown shape, as well as to stimulate the radial growth of trees. In this study, the tree-oriented silviculture approach has promoted a higher $\mathrm{dbh}$ increment and a greater development of crown area as compared to stand silviculture approach. The removal of dominant competitor trees during the first thinning can lead to a higher production of larger wood assortments, thus making such interventions more economically feasible in stands aged 10-15 years. In fact, the market of small assortments has been subject to a remarkable contraction in the last years, making early thinning in chest- nut coppices unprofitable and hardly viable even in suitable areas like Monte Amiata (Montini P, U.C. Amiata val d'Orcia, Siena, Italy, personal communication).

In this study, a higher and more regular radial growth of target trees was observed in stands characterized by frequent thinnings from above (option A), which could positively influence the timber quality and reduce the ring shake risk (Becagli et al. 2006, Fonti et al. 2002). Furthermore, our results revealed that the higher thinning frequency in option A has caused an overall higher reduction of crown coverage in the short term. However, such negative effect was counterbalanced by the high rate of crown growth for target trees, which allowed a faster recovery of the canopy cover (2-3 years after thinning) as compared with the other silvicultural options tested. Indeed, the LAI values observed in both thinned areas at the end of the study period were similar to those recorded in the control plots or reported in the literature for similar coppice stands (Cutini 2001), indicating a good stand dynamics of the plots analyzed. However, site fertility should be taken into consideration when assessing the recovery of canopy cover after thinning, since soil fertility can affect the development of tree crowns.

\section{Mixed coppices}

In mixed coppices the tree-oriented silviculture was applied to increase tree biodiversity (that naturally tends to decrease with age in coppices) and to favor the valuable timber production and natural regeneration of sporadic species. This approach can be conveniently applied in mixed stands in two different cases: (i) to promote a restricted number of sporadic species trees within the coppice in areas characterized by good site quality, an adequate presence of valuable trees and a good road density, as pointed out for high forests by Spiecker (2006) and Pelleri et al. (2013); (ii) to convert coppice stands into high forest by selecting a higher number of target trees chosen among the dominant and sporadic tree species.

In mixed coppices, single-tree localized thinning around a few number of sporadic tree species (target trees) may create suitable conditions for their growth, allowing them to reach the dominant or codominant layer fin the medium-long term, there- by tree composition can be preserved and stand biodiversity improved. Contrastingly, standard silvicultural practices can maintain the same level of tree biodiversity in the short period by preserving sporadic tree species in the dominated layer. This approach does not involve to any relevant improvement of growth conditions for sporadic tree species, therefore leading to a reduction of tree biodiversity in the medium-long period.

In this study, a positive effect of thinning on current increments in dbh was observed for all target trees of sporadic species. In particular, wild service tree (the most valuable and commom sporadic tree species in the study area) has shown differences in radial growth among different stand ages and coppice development. At half rotation period, its increase in growth after thinning is higher in young than in aged coppices, and this difference increases through time. Young target trees react faster and better to thinning, in particular those belonging to light demanding species. Moreover, in young coppices the early selection of target trees may favor their balanced development and affect their future commercial value. On the contrary, the number, the quality and further growth performances of target trees can be constrained in aged coppices, because the long period of competition experienced could compromise the stem form and architecture of sporadic and valuable tree species. Similar considerations have also been reported in the literature for high forests and other species (Duflot 1995, Perin \& Claessens 2009, Lemaire 2010).

We did not found any significant difference in tree growth between different silvicultural treatments in mixed aged coppices converted to high forests, though the growth of target trees was slightly higher in thesis A (tree-oriented silviculture) than in thesis B (stand silviculture). This could be due to the fact that the silvicultural practices have been applied after a first traditional thinning and in aged stands, and this could have influenced the growth response of target trees.

In conclusion, the tree-oriented silvicultural approach adopted in this study has proved to be sustainable from an ecological point of view (Manetti et al. 2010a, Anonymous 2014), whilst further studies and long-term surveys are needed to support its economical suitability. Since this innovative approach is not adopted yet in coppice stands in Italy, we recommend a careful planning since the first phases. The lack of an adequate professional manpower can strongly influence the production of valuable assortments, and a special attention should be payed to felling and logging operations, especially during the first thinning. In addition, a good skidding road density and stand fertility are fundamental requirements to be carefully evaluated before defining the management choices. 


\section{References}

Abetz P, Kladtke J (2002). The target tree management system. Forstw Cbl 121: 73-82.

Abrami A (2002). II bosco ceduo nell'ordinamento giuridico forestale. In: "Il bosco ceduo in Italia" [The legal order of coppice sytems. In: "The coppice system in Italy"] (Ciancio O, Nocentini S eds). Accademia Italiana di Scienze Forestali, Firenze, Italy, pp. 671-677. [in Italian]

Amorini E, Manetti MC (2002). Selvicoltura nei cedui di castagno. Sostenibilità della gestione $e$ produzione legnosa di qualità. In: "II bosco ceduo in Italia" [Silviculture in chestnut coppices. Sustainable management and valuable timber production. In: "The coppice system in Italy"] (Ciancio O, Nocentini S eds). Accademia Italiana di Scienze Forestali, Firenze, Italy, pp. 219-248. [in Italian]

Amorini E, Fabbio G, Gambi G (1979). Sistema di diradamento del bosco ceduo per l'avviamento all'altofusto. Sperimentazione in prospettiva dell'uso multiplo con il pascolo. [Thinning method of coppice for conversion to high forest. Experimental trials for multiple use with grazing]. Annali dell'Istituto Sperimentale per la Selvicoltura 10: 3-23. [in Italian]

Amorini E, Bruschini S, Manetti MC (2000). Alternative silvicultural systems in chestnut coppice: effects of the silvicultural practice on stand structure and tree growth. Ecologia Mediterranea 26 (1-2): 155-162.

Anonymous (2014). Piano della filiera legno 20122014. Documento di sintesi [Wood chain plan 2012-2014. Synthesis document] (Romano R ed). Osservatorio Foreste, INEA-MiPAF, Rome, Italy, pp. 34. [in Italian]

Bargioni E, Zanzi Sulli A (1998). The production of fodder trees in Valdagno Vicenza, Italy. In: "The Ecological History of European Forests" (Kirby KJ, Watkins $C$ eds). CAB International, Wallingford, UK, pp. 43-52.

Bastien Y, Wilhelm GJ (2000). Une sylviculture d'arbres pour produire des gros bois de qualité [A tree-oriented silviculture to produce large valuable timber]. Revue Forestière Française 5 : 407-424. [in French] - doi: 10.4267/2042/5376 Becagli C, Amorini E, Manetti MC (2006). Incidenza della cipollatura in popolamenti cedui di castagno da legno del Monte Amiata [Ring shake incidence in chestnut coppice stands on Monte Amiata]. Annali CRA, Centro di ricerca per la Selvicoltura 33: 245-256. [in Italian]

Bréda NJ (2003). Ground-based measurements of leaf area index: a review of methods, instruments and current controversies. Journal of Experimental Botany 54 (392): 2403-2417. - doi: 10.1093/jxb/erg263

Cantiani M (2006). Participatory approach in forest planning. Forest@ 3 (2): 281-299. [in Italian with English summary] - doi: 10.3832/eforo3610030281

Chapman RA, Heitzman E, Shelton MG (2006). Long-term changes in forest structures and species composition of an upland oak forest in Arkansas. Forest Ecology and Management 236: 85-92. - doi: 10.1016/j.foreco.2006.08.341 Cutini A, Fabbio G (1997). Impatto della gestione selvicolturale sulla funzionalità dei cedui di castagno [Inpact of silvicultural management on the chestnut coppices funcionality]. In: "Atti del Convegno Nazionale sul Castagno". Cison di
Valmarino (TV, Italy), 23-25 Oct 1997, pp. 245257.

Cutini A (2001). New management options in chestnut coppices: an evaluation on ecological basis. Forest Ecology and Management 141: 165-174. - doi: 10.1016/S0378-1127(00)00326-1

Ducci F, Cantiani P, Cutini A, Dettori S (2015). Forests and no wooden products in Italy. In: Proceeding of the "II International Congress of Silviculture" (Ciancio O ed). Florence (Italy) 2629 Nov 2014. AISF, Firenze, Italy, pp. 650-657.

Duflot H (1995). Le frêne en liberté [Ash free growth]. Institut pour le Développement Forestier, Paris, pp. 192. [in French]

Fantoni I, Miozzo M, Rella E (2012). Pianificazione e specie sporadiche: prime esperienze italiane in ambito del progetto LIFE+ PProSpoT [Forest planning and sporadic species. LIFE+ PProSpoT project: first experience in Italy]. Sherwood - Foreste e Alberi Oggi 184: 9-14. [in Italian] [online] URL: http://www.pprospot.it /component/remository/func-startdown/294/

Fonti P, Macchioni N, Thibaut B (2002). Ring shake in chestnut (Castanea sativa Mill.): state of the art. Annals of Forest Science 59 (2): 129140. - doi: 10.1051/forest:2002007

INFC (2005). Inventario Nazionale delle Foreste e dei Serbatoi Forestali di Carbonio [National Inventory of forests and forest Carbon pools]. Ministero delle Politiche Agricole Alimentari e Forestali, Ispettorato Generale - Corpo Forestale dello Stato, Consiglio per la Ricerca e Sperimentazione in Agricoltura Unità di ricerca per il Monitoraggio e la Pianificazione Forestale (CRA-MPF), Trento, Italy, pp. 409. [in Italian] [online] URL: http://www.sian.it/inventariofore stale/jsp/index.jsp

Kerr G (1996). The effect of heavy or free growth thinning on oak (Quercus petraea and Q. robur). Forestry 69 (4): 303-317. - doi: 10.1093 /forestry/69.4.303

Lemaire J (2010). Le chêne autrement. Produire du chêne de qualité en moins de 100 ans en futaie régulière [Oak otherwise. Produce quality oak in less than 100 years in regular high forest]. Guide technique, Institut pour le Développement Forestier, Paris, France, pp.176. [in French]

Manetti MC, Amorini E, Becagli C, Pelleri F, Pividori $M$, Schleppi $P$, Zingg $A$, Conedera $M$ (2010b). Quality wood production from chestnut (Castanea sativa Mill.) coppice forests. Comparison between different silvicultural approaches. In: Proceedings of the "1st European Congress on Chestnut - Castanea 2009" (Bonous G, Beccaro GL eds). Acta Horticolturae 866: 683-692. - doi: 10.17660/ActaHortic.2010. 866.91

Manetti MC, Amorini E, Becagli C, Pelleri F, Fratini R, Marone E (2010a). Valorizzazione dei cedui di castagno: modalità di gestione e realtà socio-economica del territorio [Enhancing chestnut coppices: silvicultural management and socio-economic context]. Annali CRA, Centro di Ricerca per la Selvicoltura 36: 97-108. [in Italian]

Manetti MC, Pelleri F, Becagli C, Conedera M, Schleppi P, Zingg A (2014). Growth dynamics and leaf area index in chestnut coppices subjected to a new silvicultural approach: singletree-oriented management. Acta Horticolturae
1043: 121-128. - doi: 10.1766o/ActaHortic.2014. 1043.15

Melini D (2013). A spatial model for sporadic tree species distribution in support of tree oriented silviculture. Annals of Silvicultural Research 37 (1): 64-68. - doi: 10.12899/ASR-751

Mori P, Pelleri F (2012). PProSpoT: un Life+ per le specie arboree sporadiche [PProSpoT: a LIFE+ project for the sporadic tree species]. Sherwood - Foreste e Alberi Oggi 179: 7-11. [in Italian]

Mori P, Pelleri F (2014). Selvicoltura per le specie arboree sporadiche [Silviculture for the sporadic tree species]. Compagnia delle Foreste, Arezzo, Italy, pp. 144. [in Italian with English summary] [online] URL: http://www.ppro spot.it/download/func-startdown/409/

Oliver CD, Larson BC (1996). Forest and dynamics. John Wiley and Sons Inc., New York, USA, pp. 520.

Oosterbaan A, Hochbichler E, Nicolescu VN, Spiecker H (2008). Silvicultural principles, phases and measures in growing valuable broadleaved tree species. Report of the COST action E42 "Growing Valuable Broadleaved Tree Species" (ValBro), Web site, pp. 11. [online] URL: http://www.valbro.uni-freiburg.de/ pdf/paper_silvics.pdf

Pelleri F, Giulietti V, Sansone D, Samola A, Nitti D (2010). La valorizzazione delle rosacee arboree: esperienze nei cedui delle Colline Metallifere (GR) [Enhancing minority tree species: the experiences in the Colline Metallifere coppice stands]. Sherwood - Foreste e Alberi Oggi 160: 5- 11 [in Italian]

Pelleri F, Sansone D, Bianchetto E, Bidini C, Sichi A (2013). Selvicoltura d'albero in fustaie di faggio: valorizzazione delle specie sporadiche e coltivazione della specie dominante [Tree-oriented silviculture in European beech high forests: silvicultural practices aimed both at enhancing sporadic species and at managing the dominant species]. Sherwood - Foreste e Alberi Oggi 190: 43-47. [in Italian with English Summary] [online] URL: http://www.ppro spot.it/component/remository/func-startdow $\mathrm{n} / 3471$

Perin J, Claessens H (2009). Considerations sur la designation et le dètourage en chênes et hetre [Considerations on the selection and free thinning in oak and beech]. Forêt wallonne 98: 3952. [in French]

Sansone D, Bianchetto E, Bidini C, Ravagni S, Nitti D, Samola A, Pelleri F (2012). Selvicoltura d'albero nei cedui giovani: interventi di valorizzazione delle specie sporadiche nell'ambito del Progetto LIFE+ PProSpoT [Tree-oriented silviculture in young coppices. Silvicultural practices to enhance sporadic species: the LIFE+ PPRoSpoT project experience]. Sherwood Foreste e Alberi Oggi 185: 5-10. [in Italian with English Summary] [online] URL: http://www. pprospot.it/component/remository/func-startd own/295/

Sevrin E (1997). Chênes sessile et péduncolé [Sessile and peduncolate oaks]. Institut pour le Développement Forestier, Paris, France, pp. 96. [in French]

Shannon CE (1948). The mathematical theory of communication. In: "The Mathematical Theory of Communication" (Shannon CE, Weaver W 
eds). University of Illinois Press, Urbana, IL, Spiecker H, Hein S, Makkonen-Spiecker K, Thies USA, pp. 29-125.

Spiecker H (2003). Silvicultural management in maintaining biodiversity and resistance of forests in Europe-temperate zone. Journal of Environmental Management 67: 55-65. - doi: 10.1016 /S0301-4797(02)00188-3

Spiecker H (2006). Minority tree species: a challenge for a multi-purpose forestry. In: "Nature based forestry in central Europe. Alternative to industrial forestry and strict preservation". Studia Forestalia Slovenica 126: 47-59.
$M$ (2009). Valuable broadleaved forests in Europe. EFI Research Report 22, Brill, Leiden, Boston, MA, USA, pp. 256. [online] URL: http:// books.google.com/books?id=FV6ug-GVPLoC Wilhelm GJ (2003). Qualification-grossissement: la stratégie sylvicole de Rhénanie-Palatinat [Qualification-sizing: the silvicultural strategy of Rhineland-Palatinate]. Rendez--Vous techniques, Office National des Forêts, Paris, France, vol. 1, pp. 4-9. [in French]

\section{Supplementary Material}

Fig. S1 - Geographic location of the two forest districts studied.

Fig. S2 - Climatic diagram of the weather station of Piancastagnaio (829 $\mathrm{m}$ a.s.l.) in Monte Amiata and Massa Marittima (732 m a.s.l.) in Colline Metallifere (mean monthly values in the last 20 years).

Link:Manetti_1827@supplo01.pdf 